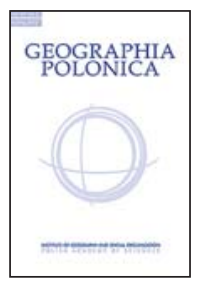

\title{
TOTAL SOLAR RADIATION IN ZAKOPANE AND AT MOUNT KASPROWY WIERCH (WESTERN CARPATHIANS, POLAND) IN 1986-2015
}

\author{
Elwira Żmudzka (D) - Kinga Kulesza \\ Faculty of Geography and Regional Studies \\ University of Warsaw \\ Krakowskie Przedmieście 30, 00-927 Warsaw: Poland \\ e-mails: e.zmudzka@uw.edu.pl•kingakulesza@uw.edu.pl
}

\begin{abstract}
The differences in the inflow of radiant energy at two stations in the Tatra Mountains were analysed, as well as the role of cloud cover in shaping of radiation conditions (using nephological characteristic days). The average increase in the annual sum of total radiation from Zakopane to Kasprowy Wierch is $193 \mathrm{MJ} \cdot \mathrm{m}^{-2}$ per $1000 \mathrm{~m}(5.3 \%)$. The influence of cloudiness on the inflow of radiant energy to these stations manifests itself i.e. in significantly smaller daily sums of total radiation from mid-May to the end of August at the peak station than at the station lying at the foot of the mountains. For the period 1986-2015, there was an increase of $0.03 \mathrm{MJ} \cdot \mathrm{m}^{-2} \cdot \mathrm{day}^{-1} \cdot$ year $^{-1}$ in the annual average daily sums of total radiation in Zakopane, despite a significant increase in the amount of cloud cover in the warm half of the year.
\end{abstract}

\section{Key words}

total radiation - cloud cover - nephological characteristic days - Tatras $・$ trend of changes

\section{Introduction}

The inflow of solar radiation is the most important factor shaping the climate on Earth and the main element in the thermal balance of the active surface. Therefore, it is extremely important to research the temporal variability and spatial diversity of solar radiation on the Earth and to identify the causes of these variations. Nowadays, satellite data is used more and more often in this kind of research, but this data is characterized by a degree of imperfection, especially in areas with varied relief (Pfeifroth et al. 2017). For this reason, research based on actinometric measurements taken at ground stations is extremely valuable. In Europe, such studies have been conducted mainly in the Alps (e.g., Reiter et al. 1982; Blumthaler et al. 1994; Heimo et al. 1998; Marty et al. 2002), while there have been relatively few studies on the Carpathians, including the Tatra 
Mountains (Konček 1974; Hess \& Olecki 1984; Olecki 1989; Wojkowski 2015). Pioneers of actinometric research in the area of the Tatra Mountains and Podhale were Fedorowicz (Fedorowicz 1926; Skibiński \& Fedorowicz 1938) and Stenz (1933a,b), who during the interwar period conducted the first measurements of solar radiation, e.g. in Zakopane and Hala Gasienicowa. The average increase in total radiation in the Carpathians is $425 \mathrm{MJ} \cdot \mathrm{m}^{-2}$ per $1000 \mathrm{~m}$ (about $11 \%)$. An increase in total radiation from October to April has been found in the entire vertical profile. In the warm season - from May to September - sums of total radiation decrease from the foothills of the mountains up to a level of 1,500-1,800 m, while above this level the sums increase (Olecki 1989; Obrębska-Starklowa et al. 1995). Similar relationships have been found in the Alps, where the increase in radiation with altitude is about 7-10\% for every $1000 \mathrm{~m}$ (Sauberer \& Dirmhirn 1958, after Barry 2008).

The amount of solar radiation reaching the surface of an area with varied relief depends not only on the latitude, but also on the sky view factor, optical airmass of the atmosphere which changes with the height and the composition of the atmosphere. Also important is the role of cloud cover, which in the mountains is characterized by specific features resulting from the thermal and dynamic influence of areas elevated above sea level and of varied relief. Therefore, modern research focuses mainly on developing models that allow for the best estimation of irradiance during clear sky conditions and relating the clear sky module to the cloudy sky module (e.g., Mueller et al. 2004). The relationship between total solar radiation and cloud cover has been the subject of research by many authors (Kimball 1928; Kasten \& Czeplak 1980; Matuszko 2009). The main aim of these analyses was to determine the dependence of the amount of radiation reaching the Earth's surface on various cloud features, mainly the amount and composition type of the clouds (Haurwitz 1945; Lumb 1964; Rimóczi-Paál 1985; Paál 1987).
The non-linear relationship between total radiation and the amount of cloud cover has been defined, among others, by Mateer (1963) and Möser and Raschke (1983). Monteith and Unsworth (1988) showed that thick, low-level layered clouds can reduce the intensity of solar radiation by $80-90 \%$. They also found that, under certain conditions, convective clouds can contribute to an increase in the instantaneous value of radiation intensity by $10-15 \%$ in relation to cloudless weather. The possibility of an increase in irradiance associated with the presence of clouds was also confirmed by Feister et al. (2015) on the basis of research conducted in the Andes.

Studies of multiannual variability in the amount of solar radiation reaching the Earth's surface have shown that, up until the end of the 1980s, there was a negative trend of changes in solar radiation (Russak 1990; Liepert 2002; Podogrocki 2002; Ohmura 2006). However, after 1990, an increase was detected in the amount of radiation reaching the Earth's surface (Bogdańska \& Podogrocki 2000; Sanchez-Lorenzo et al. 2008). The main reasons for the changes in trend direction are changes in the cloud cover regime, which are a consequence of changing circulation conditions (Russak 1990; Żmudzka 2007; Sidorenkov \& Orlov 2008), as well as changes in the transparency of the atmosphere as a result of a reduction in the amount of pollutants in the atmosphere (Chiacchio et al. 2011).

The main objective of this research is to determine the differences in the inflow of radiant energy and the characteristics of the distribution of daily sums of total solar radiation over the course of the year in Zakopane and at Kasprowy Wierch, located at the foot and peak of the Tatras, respectively. The question of the role of amount of cloud cover in the shaping of radiation conditions is also addressed. In addition to its amount, cloud cover was also described using nephological characteristic days. Furthermore, multiannual trends of changes in the daily sums of total radiation and the amount of cloud cover were defined. 


\section{Source material and research methods}

The research was based on the daily sums of total radiation and the average daily cloud cover during the period 1986-2015 from the Institute of Meteorology and Water Management station in Zakopane ( $\mathrm{h}=857 \mathrm{~m}$ above sea level, 49.293751N, 19.962834E) and from the high-altitude meteorological observatory at Kasprowy Wierch ( $h=1,991 \mathrm{~m}$ above sea level, 49.231833N, 19.981556E). The former is an urban station located on a slope with a broad concave form (Rów Podtarzański); the latter is a peak station located in a dip of the main ridge of the Western Tatras (Fig. 1).

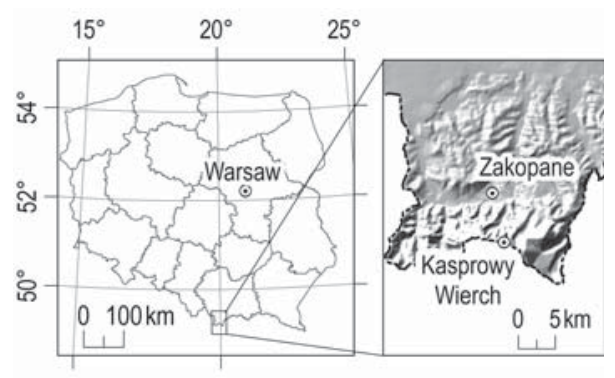

Figure 1. Location of stations used in the research

Complete data was available for cloud cover and radiation in Zakopane. The few (less than 1\%) deficiencies in the radiation data for Kasprowy Wierch were supplemented based on the data from Zakopane (the correlation coefficient of daily sums of radiation at Kasprowy Wierch and in Zakopane was over 0.8).

The data was subjected to homogeneity checks using the Alexandersson homogeneity test (Alexandersson \& Moberg 1997). Stations in Warsaw and Kołobrzeg were used as reference stations (Sanchez-Lorenzo et al. 2013). The critical value of the test at the level of $\alpha=0.05$ for a thirty-year period was obtained from the work of Khaliq and Ouarda (2007). The conducted tests showed that the potential breaking of homogeneity at the stations in Zakopane and at Kasprowy Wierch is not statistically significant in any year (Fig. 2).

The annual course of the average daily sum of radiation in the period 1986-2015 for the analysed stations was investigated. In addition, the average daily radiation sums were calculated on characteristic days in terms of amount of cloud cover: sunny $\left(\mathrm{N}_{\mathrm{av}}<20 \%\right)$ including cloudless $\left(\mathrm{N}_{\mathrm{av}}=0 \%\right)$, and overcast $\left(\mathrm{N}_{\mathrm{av}}>80 \%\right)$ including full cloud cover $\left(N_{a v}=100 \%\right)$, and their annual course was determined. The method of delimitation of nephological characteristic days adopted in the research is one of the more frequently used methods in climatological studies in Poland (Żmudzka 2012). The average daily cloud cover was calculated on the basis of data from 8 periods. The main features of the distribution of the daily sums of total solar radiation (median, interquartile range, extreme values) were determined. In addition, the following coefficients were calculated: variability $V$, skewness $A$ and flatness $K u$ for daily sums of solar radiation and average daily cloud cover. The analysis was carried out for seasonal (hereinafter spring stands for March, April, May - i.e., III, IV, V, summer for June, July, August - VI, VII, VIII, autumn for September, October, November - IX, X, $X I$ and winter for December, January, February - XII, I, II) and annual periods.

In each case, the differences in daily sums of total radiation at Kasprowy Wierch and in Zakopane were analysed. The statistical significance of the differences was determined using the Mann-Whitney $U$ test at the level of $\alpha=0.05$. The percentage share of characteristic days in terms of nephology on days with extremely large sums of total solar radiation ( $>95$ th percentile) was also calculated. In these calculations, cloudy days were also distinguished $\left(20 \% \leq N_{a v} \leq 80 \%\right)$. Furthermore, the multiannual trends of changes in the daily radiation sums and the amount of cloud cover were determined in monthly, seasonal and annual terms. The linear regression method and the Mann-Kendall trend rank method were used (Mitchell 1966) (the daily sums 

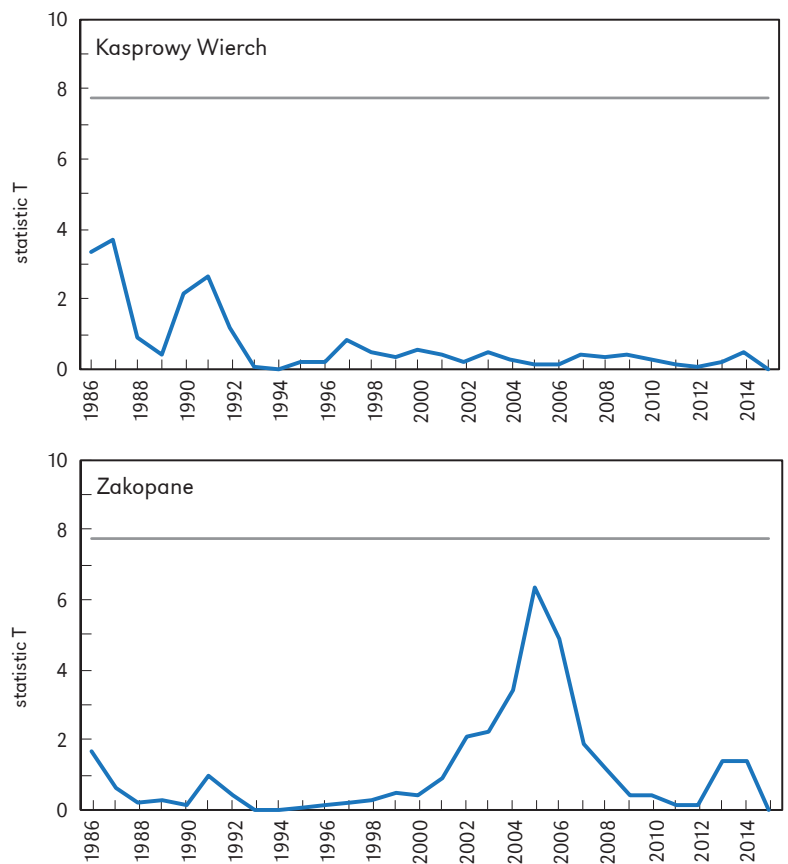

Figure 2. Values of the test statistic of Alexandersson's T test at Kasprowy Wierch and in Zakopane (1986-2015). The critical value of the test at the significance level $\alpha=0.05$ is shown by the blue line

of total solar radiation and the sums aggregated to monthly values have a distribution similar to log-normal).

\section{Results}

\section{Astronomical conditions of the inflow of solar energy to the Earth's surface at Kasprowy Wierch and in Zakopane}

The location of the analysed stations at $49^{\circ} \mathrm{N}$ means that the shortest day of the year (21/22 December) lasts 8 hours and 11 minutes, and the longest (20/21 June) nearly twice as long - 16 hours and 15 minutes. The small distance between the analysed stations means that days are virtually the same length throughout the year. The altitude of the sun at high noon is about $0.06^{\circ}$ higher at the high-altitude station (Tab. 1). On the shortest day at high noon, the sun's altitude is $17.38^{\circ}$ at Kasprowy Wierch and $17.32^{\circ}$ in Zakopane; on the longest day, these values are $64.2^{\circ}$ and $64.15^{\circ}$, respectively.
The annual total radiation at Kasprowy Wierch is $42 \%$ of the annual radiation in the upper atmosphere, while in Zakopane it is just 39\%. The sun-diminishing impact of the atmosphere in Zakopane is greater than at Kasprowy Wierch throughout the year, apart from in summer, when the transmission coefficient at Kasprowy Wierch is the lowest during the year (Tab. 2). In Zakopane, the greatest diminution in radiation during the year falls in winter. For both stations, the highest percentage of non-atmospheric radiation reaches the Earth's surface in spring.

\section{Annual course of total radiation at Kasprowy Wierch and in Zakopane}

The increase in the daily sums of total solar radiation, starting from the winter solstice, conditioned mainly by astronomical factors - especially the increase in the altitude of the Sun above the horizon - is inhibited during the summer, which is related to increasing 
Table 1. Astronomical factors of the inflow of solar radiation at Kasprowy Wierch and in Zakopane in selected months (data for 2000, 15th day of the month, local time) (calculations according to the NOAA Solar Calculator, https:// www.esrl.noaa.gov/gmd/grad/solcalc/)

\begin{tabular}{|c|c|c|c|c|}
\hline \multirow[b]{2}{*}{ Month } & \multicolumn{4}{|c|}{ Kasprowy Wierch } \\
\hline & $\begin{array}{c}\text { time } \\
\text { of sunrise }\end{array}$ & $\begin{array}{c}\text { time } \\
\text { of sunset }\end{array}$ & $\begin{array}{l}\text { length } \\
\text { of day }\end{array}$ & $\begin{array}{l}\text { sun's } \\
\text { altitude } \\
\text { at high } \\
\text { noon }\end{array}$ \\
\hline III & $5: 53$ & $17: 45$ & 11 h $52^{\prime}$ & $38.87^{\circ}$ \\
\hline VI & $3: 34$ & $19: 47$ & 16 h 13' & $64.10^{\circ}$ \\
\hline IX & $5: 17$ & $17: 53$ & 12 h $36^{\prime}$ & $43.61^{\circ}$ \\
\hline$X I I$ & $7: 29$ & $15: 42$ & 8 h 13' & $17.53^{\circ}$ \\
\hline \multirow[b]{2}{*}{ Month } & \multicolumn{4}{|c|}{ Zakopane } \\
\hline & $\begin{array}{c}\text { time } \\
\text { of sunrise }\end{array}$ & $\begin{array}{l}\text { time } \\
\text { of sunset }\end{array}$ & $\begin{array}{l}\text { length } \\
\text { of day }\end{array}$ & $\begin{array}{l}\text { sun's } \\
\text { altitude } \\
\text { at high } \\
\text { noon }\end{array}$ \\
\hline III & $5: 53$ & $17: 46$ & 11 h 53' & $38.80^{\circ}$ \\
\hline VI & $3: 34$ & $19: 48$ & 16 h $14^{\prime}$ & $64.04^{\circ}$ \\
\hline IX & $5: 17$ & $17: 53$ & 12 h $36^{\prime}$ & $43.55^{\circ}$ \\
\hline XII & $7: 29$ & $15: 42$ & 8 h 13' & $17.47^{\circ}$ \\
\hline
\end{tabular}

Table 2. Conditions for the inflow of total solar radiation at Kasprowy Wierch (KW) and in Zakopane (Z) in selected months (1986-2015)

\begin{tabular}{|c|l|c|}
\hline \multirow{2}{*}{ Month/year } & \multicolumn{2}{|c|}{ Transmission factor * } \\
\cline { 2 - 3 } & KW & Z \\
\hline III & 0.50 & 0.42 \\
VI & 0.36 & 0.38 \\
IX & 0.40 & 0.38 \\
XII & 0.43 & 0.31 \\
I-XII & 0.42 & 0.39 \\
\hline
\end{tabular}

*Transmission factor - quotient of total radiation reaching the Earth's surface via the actual atmosphere and radiation reaching the upper atmosphere

cloud cover, among other things (Fig. 3, 4). This inhibition is particularly notable in the high Tatras. The difference in the amount of cloud cover between the analysed stations is at its highest between June and August - a difference of $7 \%$ on average (Fig. 5).

The annual course of cloud cover at both stations, despite some similarity, is characterized by certain distinct features. In both cases it is complex in nature. At the highaltitude observatory, the main maximum amount of cloud cover falls in June, with the secondary maximum in November. In Zakopane, the highest cloud cover falls at the turn of autumn and winter (November), while the secondary maximum occurs in June and is less pronounced than in the high Tatras. Over the whole year, the cloud cover at Kasprowy Wierch is greater than in Zakopane. The exception is December. The consequence of the effect of cloud cover on the inflow of radiant energy is the incompatibility between the period of occurrence of the annual highest daily sums of total radiation, and the period of occurrence of the longest day and the highest altitude of the sun above the horizon. The annual highest average daily sums of total radiation at Kasprowy Wierch occur in May (16.36 MJ.m ${ }^{-2} \cdot$ day $\left.^{-1}\right)$, in Zakopane in July (16.30 $\mathrm{MJ} \cdot \mathrm{m}^{-2} \cdot$ day $\left.^{-1}\right)$, and the lowest in December (Kasprowy Wierch - $3.60 \mathrm{MJ} \cdot \mathrm{m}^{-2} \cdot \mathrm{day}^{-1}$, Zakopane - $2.63 \mathrm{MJ} \cdot \mathrm{m}^{-2} \cdot$ day $\left.^{-1}\right)$.

For the majority of the year - from September to mid-May - the daily sums of total radiation at Kasprowy Wierch are higher than in Zakopane. The biggest differences, exceeding $2 \mathrm{MJ} \cdot \mathrm{m}^{-2} \cdot \mathrm{day}^{-1}$, occur in the period from the end of March to the middle of April (Fig. 6). On individual days the differences exceed $3.0 \mathrm{MJ} \cdot \mathrm{m}^{-2}$. The development of cloud cover in the summer, especially in the high Tatras, means that from mid-May to the end of August the daily sums of total radiation at Kasprowy Wierch are lower than in Zakopane. Differences on individual days exceed $2.5 \mathrm{MJ} \cdot \mathrm{m}^{-2}$, with maximum average monthly differences of $1.53 \mathrm{MJ} \cdot \mathrm{m}^{-2}$ (15.06 - 15.07).

In seasonal terms, the differences between the average daily sums of total solar radiation at Kasprowy Wierch and in Zakopane are significant throughout the year, with 


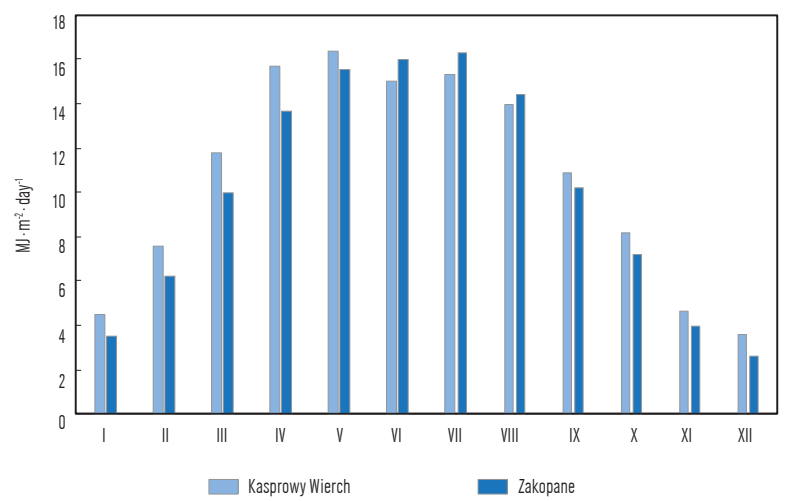

Figure 3. Annual course (in months) of average daily sums of total radiation ( $\mathrm{MJ} \cdot \mathrm{m}^{-2} \cdot \mathrm{day}^{-1}$ ) at Kasprowy Wierch and in Zakopane (1986-2015)
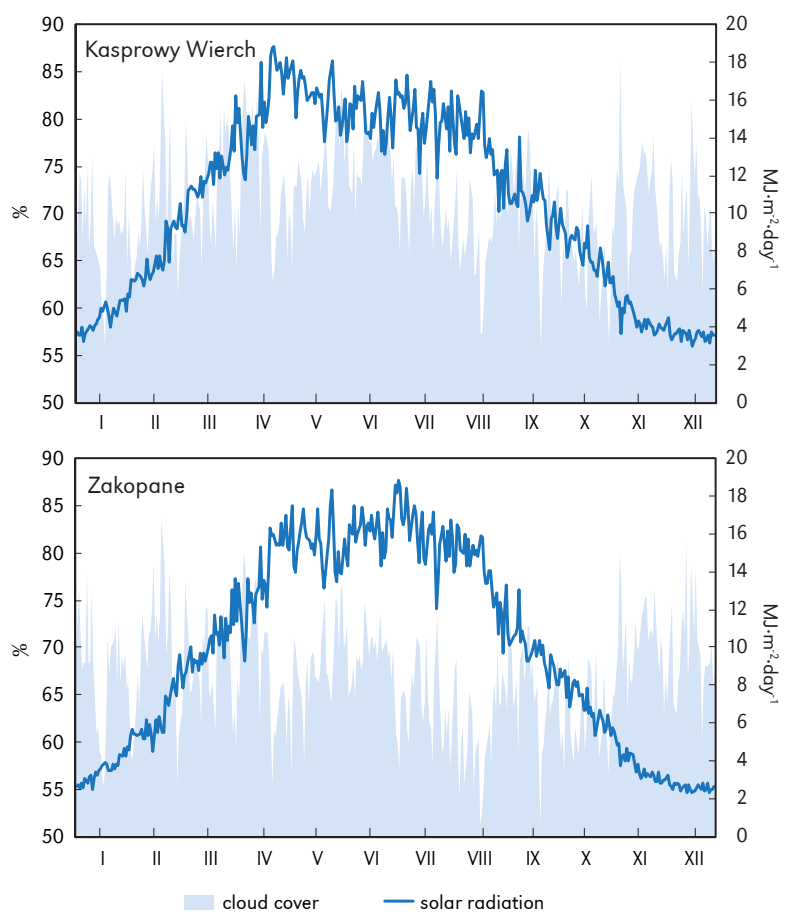

Figure 4. Annual course of the average daily sum of total radiation $\left(\mathrm{MJ} \cdot \mathrm{m}^{-2} \cdot \mathrm{day}^{-1}\right)$ and the average daily cloud cover (\%) at Kasprowy Wierch and in Zakopane (1986-2015)

values from $-0.8 \mathrm{MJ} \cdot \mathrm{m}^{-2} \cdot \mathrm{day}^{-1}$ in summer to $1.6 \mathrm{MJ} \cdot \mathrm{m}^{-2} \cdot \mathrm{day}^{-1}$ in spring. Throughout the year, the average daily inflow of total solar radiation is higher at Kasprowy Wierch by $0.6 \mathrm{MJ} \cdot \mathrm{m}^{-2}$ (Tab. 3).

Over the whole year, in seasonal terms, the maximum, minimum and first and third quartile values of the daily sums of radiation are higher at Kasprowy Wierch (Fig. 7). Only in summer are the average daily sum of total radiation, the median and the interquartile range values higher at the foot of the mountains. The differences between the maximum values of total radiation at the two 

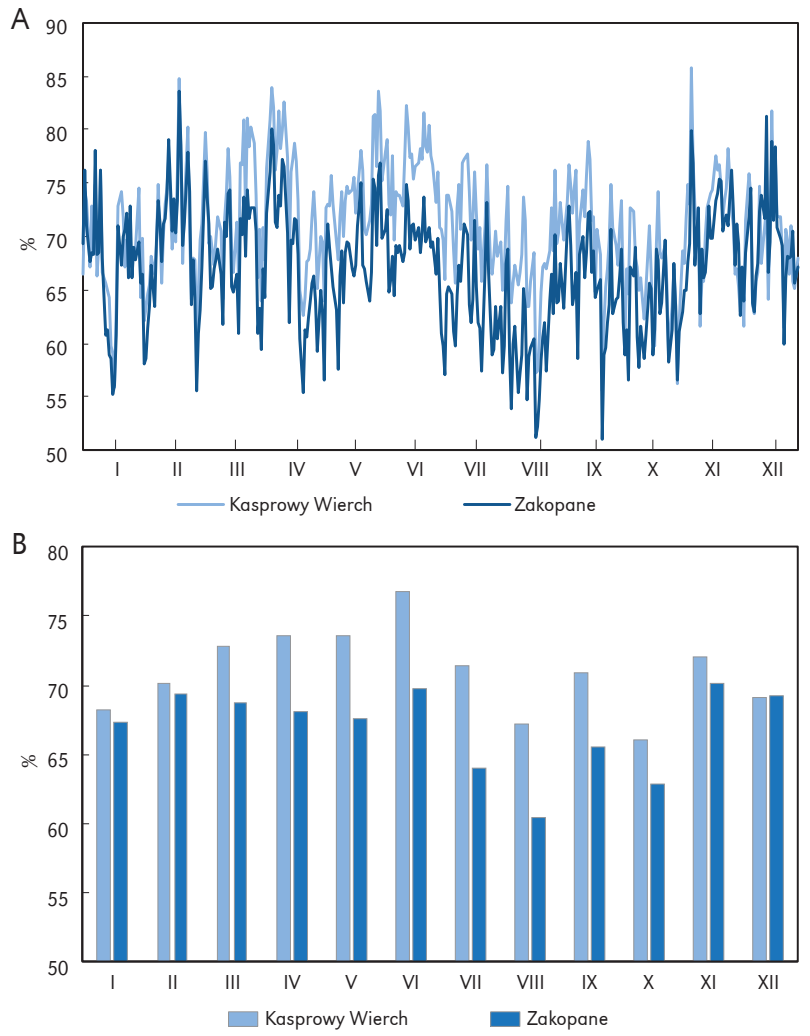

Figure 5. Annual course of amount of cloud cover (\%) at Kasprowy Wierch and in Zakopane (1986-2015): A) daily averages, B) monthly averages

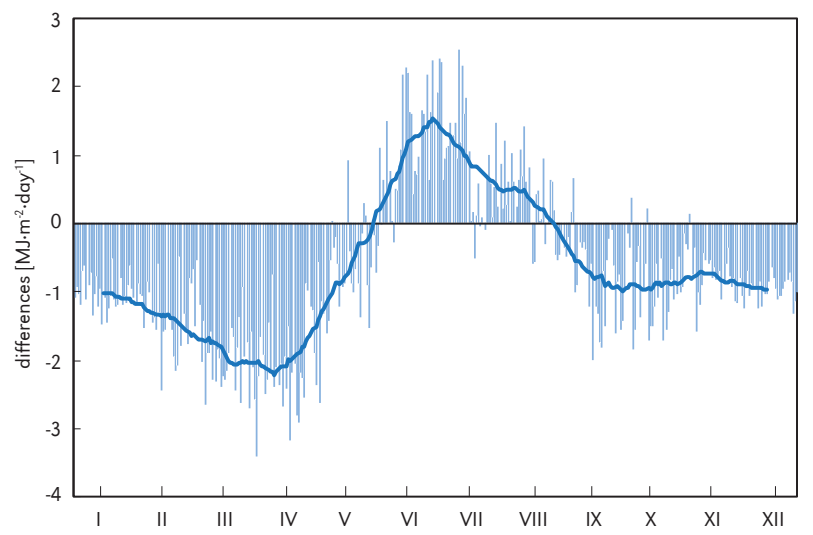

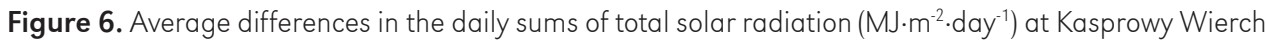
and in Zakopane (1986-2015). Black line - 31-day moving average

stations are greater than for the minimum values, which indicates the higher annual amplitude of the daily sums of radiation at the high-altitude station. The annual highest daily sums of total radiation, reaching a value of $35.8 \mathrm{MJ} \cdot \mathrm{m}^{-2} \cdot$ day $^{-1}$ at Kasprowy Wierch and 
Table 3. Average daily sum of total solar radiation $\left(\mathrm{MJ} \cdot \mathrm{m}^{-2} \cdot \mathrm{day}^{-1}\right)$ at Kasprowy Wierch and in Zakopane and average difference between the two stations (1986-2015). Statistically significant differences at the level of $\alpha=0.05$ are shown in bold

\begin{tabular}{|l|c|c|c|c|c|}
\hline \multicolumn{1}{|c|}{ Station } & III-V & VI-VIII & IX-XI & XII-II & I-XII \\
\hline Kasprowy Wierch & 14.6 & 14.8 & 7.9 & 5.1 & 10.6 \\
Zakopane & 13.0 & 15.6 & 7.1 & 4.0 & 10.0 \\
\hline Difference & $\mathbf{1 . 6}$ & $-\mathbf{0 . 8}$ & $\mathbf{0 . 8}$ & $\mathbf{1 . 1}$ & $\mathbf{0 . 6}$ \\
\hline
\end{tabular}

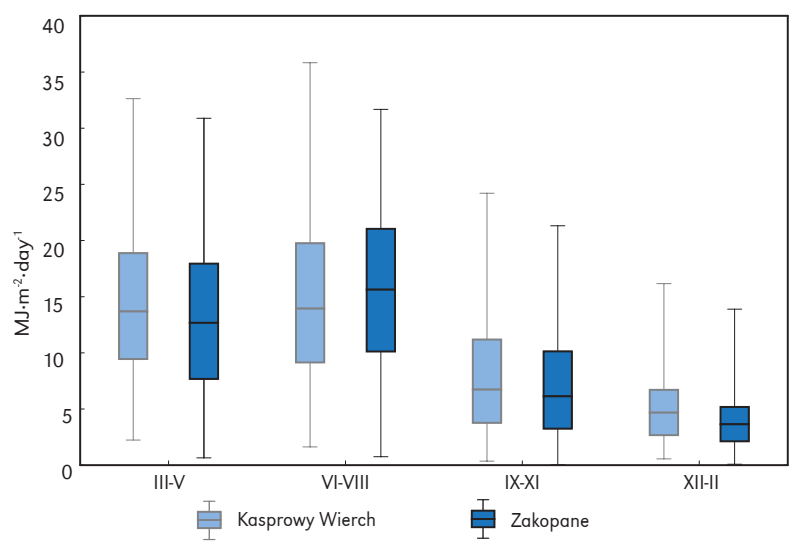

Figure 7. Distribution of the daily sums of total solar radiation $\left(\mathrm{MJ} \cdot \mathrm{m}^{-2} \cdot \mathrm{day}^{-1}\right)$ in different seasons at Kasprowy Wierch and in Zakopane (1986-2015). Central line - median; box - I and III quartiles; whiskers - minimum and maximum values

31.7 MJ.m-2 $\cdot$ day $^{-1}$ in Zakopane, occur in summer, and the lowest $-0.36 \mathrm{MJ} \cdot \mathrm{m}^{-2} \cdot \mathrm{day}^{-1}$ at Kasprowy Wierch and $0.04 \mathrm{MJ} \cdot \mathrm{m}^{-2} \cdot \mathrm{day}^{-1}$ in Zakopane - in autumn.

The dispersion of the daily sums of total solar radiation at the analysed stations is higher in the colder than the warmer part of the year: it is highest in autumn at Kasprowy Wierch, and in winter in Zakopane. The standard deviation is $65 \%$ and $69 \%$ percent, respectively, of the average daily sum (Tab. 4). The winter period also sees the largest variation in the average daily cloud cover at the two stations. The lowest values of the coefficient of variability in the daily sums of total solar radiation occur at Kasprowy Wierch in summer, and in Zakopane in spring. Summer is also characterized by the smallest variability in average daily cloud cover. The distribution of the daily sums of total radiation at the two stations, regardless of the season (except for the summer period in Zakopane), is characterized by a positive asymmetry, and the average daily cloud cover by a negative asymmetry.

The value of the 95th percentile of the daily sums of total radiation changes throughout the year at Kasprowy Wierch from $11.8 \mathrm{MJ} \cdot \mathrm{m}^{-2} \cdot \mathrm{day}^{-1}$ in winter to $27.7 \mathrm{MJ} \cdot \mathrm{m}^{-2} \cdot \mathrm{day}^{-1}$ in summer, and in Zakopane from 9.5 MJ.m $\mathrm{m}^{-2} \cdot$ day $^{-1}$ in winter to $27.2 \mathrm{MJ} \cdot \mathrm{m}^{-2} \cdot$ day $^{-1}$ in summer (Tab. 5). In the spring, the values of the 95th percentile of the daily sums of total radiation are about 1.5 times higher than in the autumn.

On days with an extremely high inflow of radiant energy ( $>95$ th percentile), the structure of characteristic days in terms of nephrology is similar at both stations. Most common (over $70 \%$ of days) are cloudy days (20\% $\leq \mathrm{N}_{\mathrm{av}} \leq 80 \%$ ), and least common are overcast days $\left(\mathrm{N}_{\mathrm{av}}>80 \%\right)$ (Tab. 6). This structure 
Table 4. Values of coefficients of variability $V$, skewness $A$ and flatness $K u$ of the daily sums of total solar radiation and average daily cloud cover, by season and by year, at Kasprowy Wierch (KW) and in Zakopane (Z) (1986-2015)

\begin{tabular}{|c|c|c|c|c|c|c|}
\hline \multicolumn{7}{|c|}{ Daily sums of total solar radiation } \\
\hline Coeff. & station & $I I I-V$ & VI-VIII & $|X-X|$ & $X I I-I I$ & I-XII \\
\hline \multirow{2}{*}{ V } & KW & 0.44 & 0.48 & 0.65 & 0.63 & 0.66 \\
\hline & z & 0.51 & 0.46 & 0.66 & 0.69 & 0.72 \\
\hline \multirow{2}{*}{$A$} & KW & 0.38 & 0.31 & 0.67 & 0.47 & 0.68 \\
\hline & Z & 0.16 & -0.02 & 0.65 & 0.50 & 0.74 \\
\hline \multirow{2}{*}{ Ku } & KW & -0.41 & -0.53 & 0.16 & 5.60 & -0.01 \\
\hline & Z & -0.72 & -0.86 & -0.13 & 6.88 & -0.41 \\
\hline \multicolumn{7}{|c|}{ Average daily cloud cover } \\
\hline Coeff. & station & $I I I-V$ & VI-VIII & $|X-X|$ & $\mathrm{XII-II}$ & $|-X| \mid$ \\
\hline \multirow{2}{*}{ V } & KW & 0.35 & 0.32 & 0.41 & 0.45 & 0.39 \\
\hline & z & 0.38 & 0.38 & 0.42 & 0.43 & 0.40 \\
\hline \multirow{2}{*}{$A$} & KW & -0.92 & -0.63 & -1.04 & -1.01 & -0.79 \\
\hline & Z & -0.61 & -0.50 & -0.77 & -0.96 & -0.72 \\
\hline \multirow{2}{*}{ Ku } & KW & 0.04 & -0.17 & -0.40 & -0.46 & -0.15 \\
\hline & z & -0.17 & -0.52 & -0.43 & -0.17 & -0.32 \\
\hline
\end{tabular}

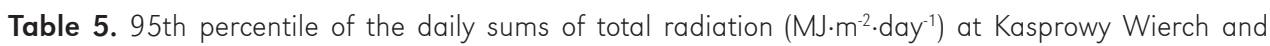
in Zakopane (1986-2015)

\begin{tabular}{|l|c|c|c|c|c|}
\hline \multicolumn{1}{|c|}{ Station } & III-V & VI-VIII & IX-X| & XII-II & I-XII \\
\hline Kasprowy Wierch & 26.8 & 27.7 & 18.3 & 11.8 & 24.6 \\
Zakopane & 25.0 & 27.2 & 16.3 & 9.5 & 24.0 \\
\hline
\end{tabular}

Table 6. Percentage of characteristic days in terms of the amount of cloud cover on days with extremely large sums of total radiation (> 95th percentile) and on all days at Kasprowy Wierch (KW) and in Zakopane (Z) (1986-2015)

\begin{tabular}{|l|c|c|c|c|}
\hline \multirow{2}{*}{ Days } & \multicolumn{2}{|c|}{$\begin{array}{c}\text { Days with extremely large sums } \\
\text { of radiation }\end{array}$} & \multicolumn{2}{c|}{ All days } \\
\cline { 2 - 5 } & KW & Z & KW & Z \\
\hline Sunny (including cloudless) & $20.9(0.4)$ & $27.1(1.6)$ & $7.4(0.9)$ & $8.0(1.7)$ \\
Cloudy & 76.0 & 72.4 & 44.6 & 51.9 \\
Overcast (including full cloud cover) & $3.1(-)$ & $0.5(-)$ & $48.0(11.7)$ & $40.1(5.3)$ \\
\hline
\end{tabular}


differs from the structure calculated on the basis of all days when overcast and cloudy days occur with a similar frequency, which constitute from over $40 \%$ to $52 \%$ of days. In the multiannual perspective, there are about three times fewer sunny days compared to days with extremely large sums of total radiation. On average, at both stations - especially at Kasprowy Wierch - there are many days with full cloud cover, whereas on days with extremely large sums of radiation, such days did not occur.

The maximum amount of cloud cover on days with extremely high sums of total radiation was $90.6 \%$ at Kasprowy Wierch and $87.5 \%$ in Zakopane. The days with the highest sum of total radiation - $35.83 \mathrm{MJ} \cdot \mathrm{m}^{-2} \cdot$ day $^{-1}$ at Kasprowy Wierch (04.06.1988) and $31.68 \mathrm{MJ} \cdot \mathrm{m}^{-2} \cdot$ day $^{-1}$ in Zakopane (24.06.2007) were cloudy days (the average daily amount of cloud cover was $45.3 \%$ and $31.3 \%$, respectively).

\section{Variability of daily sums of total radiation in the annual cycle on sunny days $\left(\mathrm{N}_{\mathrm{av}}<20 \%\right)$ at Kasprowy Wierch and in Zakopane}

The annual course of the daily sums of total solar radiation on sunny days is similar to the course on all days (Tab. 7). However, low cloud cover affects the relative increase in sums of radiation, with average values from 2-3 $\mathrm{MJ} \cdot \mathrm{m}^{-2} \cdot \mathrm{day}^{-1}$ in autumn up to 10-13 MJ.m ${ }^{-2} \cdot$ day $^{-1}$ in summer. Throughout the year, this value is larger in the high Tatras than in the foothills. A particularly large difference in the size of the increase in the daily sums of radiation on sunny days between the stations was found in summer. Throughout the year, the average daily sum of total solar radiation on sunny days in the high Tatras is significantly higher than in the foothills (Tab. 7). It is worth noting that the number of sunny days at Kasprowy Wierch in the summer is almost half that in Zakopane (Tab. 8).

A special case of sunny days are cloudless days $\left(\mathrm{N}_{\mathrm{av}}=0 \%\right)$. The average daily sums of total radiation, calculated on the basis of all days, constitute from $43 \%$ in summer to $73 \%$ in spring of the average daily sum of radiation on cloudless days at Kasprowy Wierch, and from 51\% in summer to $76 \%$ in spring in Zakopane. In autumn and winter, they constitute from $59 \%$ to $68 \%$ of the sum of radiation on cloudless days. During the whole year on cloudless days, the average daily sums of total solar radiation are higher at the high-altitude station than in Zakopane. The differences are statistically significant in autumn and winter (Tab. 7).

The average and extreme ( $>$ 95th percentile) daily sums of total solar radiation on clear days in spring and autumn, and throughout the year, are smaller than their corresponding values calculated on the basis of data from sunny days (Tab. 7, 9). However, it should be noted that statistical inference was carried out with regard to samples of different sizes (Tab. 8). There are very few cloudless days - in the summer there was only one cloudless day at both stations at the same time, and in the spring there were nine such days.

On sunny days, the smallest daily sums of total radiation range from $3.2 \mathrm{MJ} \cdot \mathrm{m}^{-2} \cdot$ day $^{-1}$ in Zakopane and 3.4 $\mathrm{MJ} \cdot \mathrm{m}^{-2} \cdot$ day $^{-1}$ in Kasprowy Wierch in winter to $15.4 \mathrm{MJ} \cdot \mathrm{m}^{-2}$. day ${ }^{-1}$ in Zakopane and $15.1 \mathrm{MJ} \cdot \mathrm{m}^{-2} \cdot$ day $^{-1}$ at Kasprowy Wierch in summer. In the high Tatras, the smallest daily sums of radiation during sunny days throughout the year are higher than in Zakopane (Fig. 8). Only in summer is the minimum value of daily sums of total radiation higher in Zakopane.

\section{Variability of daily sums of total radiation in the annual cycle on overcast days ( $\left.\mathrm{N}_{\mathrm{av}}>80 \%\right)$ at Kasprowy Wierch and in Zakopane}

The average daily sum of total solar radiation on overcast days $\left(\mathrm{N}_{\mathrm{av}}>80 \%\right)$ is highest at Kasprowy Wierch during the spring, and in Zakopane in summer (Tab. 10). At both stations, the smallest average sums throughout the year fall in winter. During the summer on overcast days, the average daily inflow 
Table 7. The average daily sum of total solar radiation $\left(\mathrm{MJ} \cdot \mathrm{m}^{-2} \cdot \mathrm{day}^{-1}\right)$ on sunny days $\left(\mathrm{N}_{\mathrm{av}}<20 \%\right)(\mathrm{A})$ and cloudless days $\left(\mathrm{N}_{\mathrm{av}}=0 \%\right.$ ) (B) at Kasprowy Wierch and in Zakopane, and the average difference between the two stations (1986-2015). Statistically significant differences at the level of $\alpha=0.05$ are shown in bold

\begin{tabular}{|c|c|c|c|c|c|c|c|c|c|c|}
\hline \multirow{2}{*}{ Station } & \multicolumn{2}{|c|}{$I I I-V$} & \multicolumn{2}{|c|}{ VIIVIII } & \multicolumn{2}{|c|}{$|X-X|$} & \multicolumn{2}{|c|}{ XII-II } & \multicolumn{2}{|c|}{$|-X| \mid$} \\
\hline & A & B & A & B & A & B & A & B & A & B \\
\hline Kasprowy Wierch & 22.4 & 20.0 & 27.3 & 34.3 & 13.8 & 12.6 & 8.3 & 8.7 & 15.0 & 11.4 \\
\hline Zakopane & 20.1 & 17.2 & 25.2 & 30.6 & 11.7 & 10.5 & 6.4 & 6.6 & 13.0 & 9.2 \\
\hline Difference & 2.3 & 2.8 & 2.1 & 3.7 & 2.1 & 2.1 & 1.9 & 2.1 & 2.0 & 2.2 \\
\hline
\end{tabular}

Table 8. Percentage of sunny days ( $\left.N_{a v}<20 \%\right)$ (A) and cloudless days $\left(N_{a v}=0 \%\right)$ (B) out of the total number of days at Kasprowy Wierch and in Zakopane, and at both stations simultaneously (1986-2015)

\begin{tabular}{|l|c|c|c|c|c|c|c|c|c|c|}
\hline \multirow{3}{*}{ Station } & \multicolumn{2}{|c|}{$I I I-V$} & \multicolumn{2}{c|}{ VI-VIII } & \multicolumn{2}{c|}{ IX-XI } & \multicolumn{2}{c|}{ XII-II } & \multicolumn{3}{c|}{ I-XII } \\
\cline { 2 - 13 } & A & B & A & B & A & B & A & B & A & B \\
\hline Kasprowy Wierch & 5.3 & 0.3 & 3.0 & 0.0 & 9.2 & 0.8 & 12.2 & 2.4 & 7.4 & 0.9 \\
Zakopane & 7.0 & 1.1 & 5.4 & 0.2 & 9.2 & 1.8 & 10.4 & 3.7 & 8.0 & 1.7 \\
\hline Concurrently & 4.5 & 0.3 & 2.7 & 0.0 & 6.9 & 0.5 & 8.9 & 1.6 & 5.7 & 0.6 \\
\hline
\end{tabular}

Table 9. 95th percentile of daily sums of total radiation $\left(\mathrm{MJ} \cdot \mathrm{m}^{-2} \cdot\right.$ day $\left.^{-1}\right)$ on sunny days $\left(\mathrm{N}_{\mathrm{av}}<20 \%\right)(\mathrm{A})$ and cloudless days $\left(\mathrm{N}_{\mathrm{av}}=0 \%\right)(\mathrm{B})$ at Kasprowy Wierch and in Zakopane (1986-2015)

\begin{tabular}{|l|c|c|c|c|c|c|c|c|c|c|}
\hline \multirow{2}{*}{ Station } & \multicolumn{2}{|c|}{$|I|-V$} & \multicolumn{2}{c|}{ VI-VIII } & \multicolumn{2}{c|}{ IX-XI } & \multicolumn{2}{c|}{ XIIII } & \multicolumn{3}{c|}{ I-XII } \\
\cline { 2 - 12 } & A & B & A & B & A & B & A & B & A & B \\
\hline Kasprowy Wierch & 30.4 & 26.0 & 33.1 & - & 20.7 & 17.2 & 14.0 & 14.4 & 28.3 & 18.0 \\
Zakopane & 28.2 & 22.1 & 29.8 & - & 18.5 & 13.6 & 11.8 & 11.7 & 25.5 & 21.0 \\
\hline
\end{tabular}

of total radiation is the same at both stations. For the rest of the year, the daily sums of total radiation on overcast days are significantly higher in the high Tatras.

The greatest number of overcast days at Kasprowy Wierch occur in spring (51.0\% of all days), and in Zakopane in winter (47.4\% of days) (Tab. 11). The biggest difference in the number of overcast days between the stations occurs in summer.

On overcast days, the median of the daily sums of total solar radiation at Kasprowy Wierch and in Zakopane is about 2.5 times higher than on sunny days in winter and spring, and about 3.5 times higher in summer and autumn. At the high-altitude station, the highest median during the year occurs in spring, and in Zakopane in summer (Fig. 9). During the whole year, the maximum and minimum daily sums of total solar radiation are higher at Kasprowy Wierch than in Zakopane. The exception occurs in the summer period, when the highest sum and the 75th and 95th percentile of daily sums of total solar radiation are higher in Zakopane than at the peak station (Fig. 9, Tab. 12). 

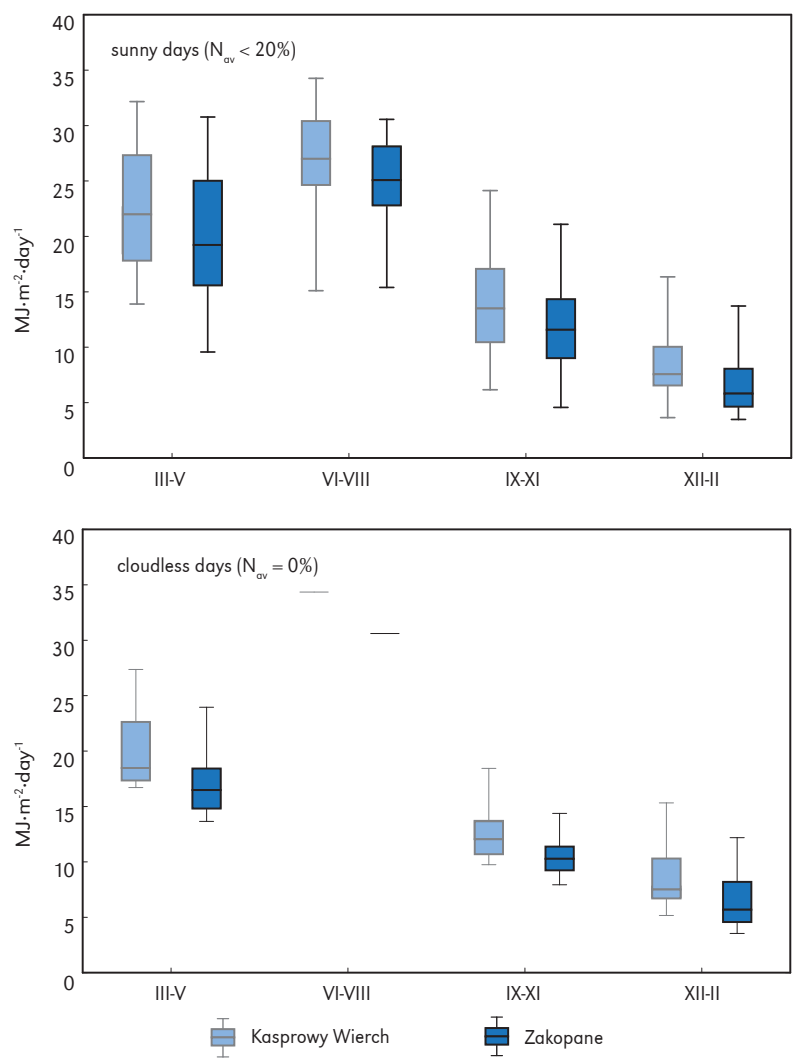

Figure 8. Distribution of daily sums of total solar radiation $\left(\mathrm{MJ} \cdot \mathrm{m}^{-2} \cdot \mathrm{day}^{-1}\right)$ on characteristic days in terms of amount of cloud cover: sunny days $\left(\mathrm{N}_{\mathrm{av}}<20 \%\right)$ and cloudless days $\left(\mathrm{N}_{\mathrm{av}}=0 \%\right)$ at Kasprowy Wierch and in Zakopane (1986-2015). Central line - median; box - I and III quartiles; whiskers - minimum and maximum values

Table 10. The average daily sum of total solar radiation $\left(\mathrm{MJ} \cdot \mathrm{m}^{-2} \cdot\right.$ day $\left.^{-1}\right)$ on overcast days $\left(\mathrm{N}_{\mathrm{av}}>80 \%\right)$ (A) and days with full cloud cover $\left(\mathrm{N}_{\mathrm{av}}=100 \%\right)(\mathrm{B})$ at Kasprowy Wierch and in Zakopane, and the average difference between the two stations (1986-2015). Statistically significant differences at the level of $\alpha=0.05$ are shown in bold

\begin{tabular}{|l|c|c|c|c|c|c|c|c|c|c|}
\hline \multirow{2}{*}{ Station } & \multicolumn{2}{|c|}{$I I I-V$} & \multicolumn{2}{c|}{ VI-VIII } & \multicolumn{2}{c|}{ IX-XI } & \multicolumn{2}{c|}{ XII-II } & \multicolumn{3}{c|}{ I-XII } \\
\cline { 2 - 12 } & A & B & A & B & A & B & A & B & A & B \\
\hline Kasprowy Wierch & 9.9 & 9.1 & 8.3 & 5.9 & 4.6 & 3.9 & 3.4 & 3.2 & 6.5 & 5.7 \\
Zakopane & 7.8 & 3.4 & 8.3 & 3.1 & 3.8 & 1.7 & 2.6 & 1.5 & 5.5 & 2.5 \\
\hline Difference & $\mathbf{2 . 2}$ & $\mathbf{5 . 7}$ & 0.0 & $\mathbf{2 . 8}$ & $\mathbf{0 . 8}$ & $\mathbf{2 . 2}$ & $\mathbf{0 . 8}$ & $\mathbf{1 . 7}$ & $\mathbf{1 . 0}$ & $\mathbf{3 . 2}$ \\
\hline
\end{tabular}

On days with full cloud cover $\left(\mathrm{N}_{\text {av }}=100 \%\right)$ the daily sums of total radiation are higher in spring and summer than in autumn and winter, with the highest values occurring in spring (Tab. 10). Throughout the year, the difference in the amount of inflowing radiant energy to Kasprowy Wierch and Zakopane on these days is statistically significant, and the individual characteristics of the distribution of daily sums of solar radiation assume 
Table 11. Percentage of overcast days ( $\mathrm{N}_{\mathrm{av}}>80 \%$ ) (A) and days with full cloud cover ( $\left.\mathrm{N}_{\mathrm{av}}=100 \%\right)$ (B) out of the total number of days at Kasprowy Wierch and in Zakopane, and at both stations simultaneously (1986-2015)

\begin{tabular}{|l|c|c|c|c|c|c|c|c|c|c|}
\hline \multirow{2}{*}{ Station } & \multicolumn{2}{|c|}{$I I I-V$} & \multicolumn{2}{c|}{ VI-VIII } & \multicolumn{2}{c|}{ IX-XI } & \multicolumn{2}{c|}{ XII-II } & \multicolumn{3}{c|}{ I-XII } \\
\cline { 2 - 12 } & A & B & A & B & A & B & A & B & A & B \\
\hline Kasprowy Wierch & 51.0 & 12.7 & 43.5 & 8.4 & 47.8 & 12.6 & 49.7 & 13.0 & 48.0 & 11.7 \\
Zakopane & 41.6 & 5.5 & 31.3 & 3.6 & 40.5 & 6.2 & 47.3 & 5.8 & 40.1 & 5.3 \\
\hline Concurrently & 38.7 & 3.7 & 29.9 & 2.8 & 34.2 & 3.8 & 39.1 & 2.8 & 35.5 & 3.3 \\
\hline
\end{tabular}
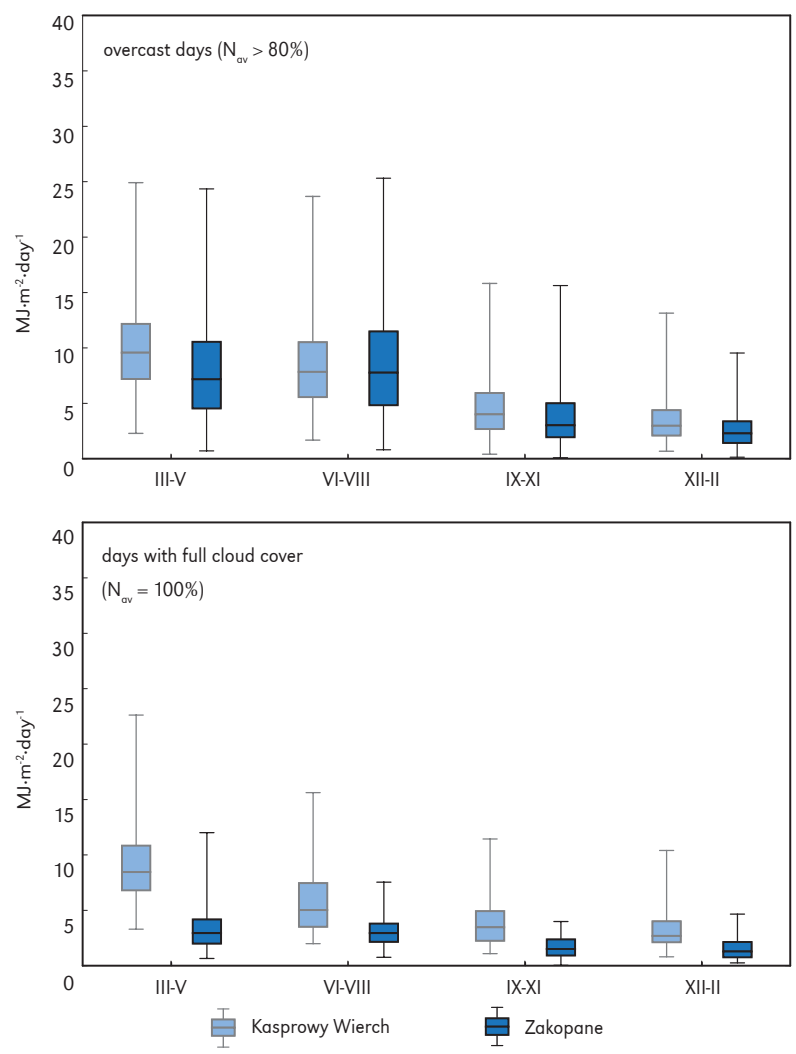

Figure 9. Distribution of daily sums of total solar radiation $\left(\mathrm{MJ} \cdot \mathrm{m}^{-2} \cdot \mathrm{day}^{-1}\right)$ on characteristic days in terms of amount of cloud cover: overcast days $\left(\mathrm{N}_{\mathrm{av}}>80 \%\right)$ and days with full cloud cover $\left(\mathrm{N}_{\mathrm{ov}}=100 \%\right)$ at Kasprowy Wierch and in Zakopane (1986-2015). Central line - median; box - I and III quartiles; whiskers - minimum and maximum values

higher values at Kasprowy Wierch than in Zakopane (Fig. 9, Tab. 12). Spring also stands out in terms of nephological conditions. At Kasprowy Wierch, this is the season with the greatest cloud cover during the year and it is characterized by a large number of days with full cloud cover in the Tatra profile (Tab. 11).

During the whole year, the lowest medians and first and third quartiles of the daily sums of total solar radiation occurred on days with full cloud cover (except for the third quartile 
Table 12. 95th percentile of daily sums of total radiation $\left(\mathrm{MJ} \cdot \mathrm{m}^{-2} \cdot\right.$ day $\left.^{-1}\right)$ on overcast days $\left(\mathrm{N}_{\mathrm{ov}}>80 \%\right)(\mathrm{A})$ and days with full cloud cover $\left(\mathrm{N}_{\mathrm{av}}=100 \%\right)(\mathrm{B})$ at Kasprowy Wierch and in Zakopane (1986-2015)

\begin{tabular}{|l|c|c|c|c|c|c|c|c|c|c|}
\hline \multirow{2}{*}{ Station } & \multicolumn{2}{|c|}{$|I|-\mathrm{V}$} & \multicolumn{2}{c|}{ VI-VIII } & \multicolumn{2}{c|}{ IX-XI } & \multicolumn{3}{c|}{ XII-I } & \multicolumn{3}{c|}{ I-XII } \\
\cline { 2 - 11 } & A & B & A & B & A & B & A & B & A & B \\
\hline Kasprowy Wierch & 16.8 & 15.5 & 15.1 & 11.2 & 9.7 & 8.2 & 7.3 & 6.5 & 14.5 & 11.9 \\
Zakopane & 16.0 & 6.5 & 15.7 & 5.7 & 9.3 & 3.6 & 6.1 & 3.6 & 13.9 & 5.5 \\
\hline
\end{tabular}

in winter at Kasprowy Wierch). In summer and winter, and in the case of the first quartile in autumn, the highest values occurred on cloudless days. In the transitional seasons, spring and autumn, they occurred on sunny days.

\section{Multiannual variability of daily sums of total solar radiation and average daily cloud cover at Kasprowy Wierch and in Zakopane}

In the multiannual analysis, irregular changes in the values of both climate elements are observable from year to year. Linear trends explain a small percentage of variability in both the daily sums of total solar radiation and the average daily cloud cover (Fig. 10, 11). The annual average daily sums of total radiation in Zakopane saw significant increases (Tab. 13). This was mainly a consequence of the significant increase in the amount of radiation in the warm half of the year (in monthly terms: in April and August). This occurred despite the significant increase in cloud cover in Zakopane in this part of the year. There was also a significant increase in cloud cover at the foot of the mountains in winter. In the remaining seasons, no trend was identified for changes in the analysed climate elements. In monthly terms, a significant increase in the amount of cloud

Table 13. Direction coefficients of the trend of changes in daily sums of total radiation $\left(\mathrm{MJ} \cdot \mathrm{m}^{-2} \cdot \mathrm{day}^{-1} \cdot \mathrm{year}^{-1}\right)$ and the average daily amount of cloud cover $\left(\% \cdot y e a r^{-1}\right)$ at Kasprowy Wierch and in Zakopane (1986-2015). Statistically significant coefficients at the level of $\alpha=0.05$ are shown in bold

\begin{tabular}{|c|c|c|c|c|c|c|c|c|c|c|c|c|}
\hline \multirow{2}{*}{ Station } & । & ॥ & III & IV & V & VI & VII & VIII & IX & $x$ & $X I$ & XII \\
\hline & \multicolumn{12}{|c|}{ Total solar radiation } \\
\hline Kasprowy Wierch & -0.03 & -0.02 & 0.01 & 0.05 & -0.05 & 0.01 & -0.04 & 0.01 & 0.01 & -0.02 & 0.00 & 0.02 \\
\hline \multirow[t]{2}{*}{ Zakopane } & -0.01 & -0.01 & 0.03 & 0.08 & 0.02 & 0.04 & 0.03 & 0.06 & 0.03 & 0.01 & 0.02 & 0.02 \\
\hline & \multicolumn{12}{|c|}{ Cloud cover } \\
\hline Kasprowy Wierch & 0.60 & 0.25 & -0.10 & -0.24 & 0.03 & -0.04 & 0.05 & -0.07 & -0.12 & 0.20 & -0.12 & 0.06 \\
\hline Zakopane & 0.59 & 0.40 & -0.10 & -0.19 & 0.07 & 0.04 & 0.07 & -0.05 & -0.05 & 0.28 & -0.15 & 0.07 \\
\hline \multirow{2}{*}{ Station } & \multicolumn{2}{|c|}{$\| I I-V$} & VI-VIII & \multicolumn{2}{|r|}{$|X-X|$} & \multicolumn{2}{|c|}{$X I I-I I$} & \multicolumn{2}{|l|}{ IV-IX } & $X-111$ & \multicolumn{2}{|c|}{$I-X||$} \\
\hline & \multicolumn{12}{|c|}{ Total solar radiation } \\
\hline Kasprowy Wierch & 0.0 & & -0.01 & & -0.00 & \multicolumn{2}{|c|}{-0.01} & -0.00 & & -0.01 & \multicolumn{2}{|c|}{-0.00} \\
\hline \multirow[t]{2}{*}{ Zakopane } & \multicolumn{2}{|c|}{0.04} & 0.05 & & 0.02 & \multicolumn{2}{|c|}{-0.00} & 0.05 & & 0.01 & \multicolumn{2}{|c|}{0.03} \\
\hline & \multicolumn{12}{|c|}{ Cloud cover } \\
\hline Kasprowy Wierch & \multicolumn{2}{|c|}{-0.10} & -0.02 & & -0.01 & \multicolumn{2}{|c|}{0.31} & 0.15 & & -0.06 & \multicolumn{2}{|c|}{0.04} \\
\hline Zakopane & \multicolumn{2}{|c|}{-0.07} & 0.02 & & 0.03 & \multicolumn{2}{|c|}{0.35} & 0.18 & & -0.02 & \multicolumn{2}{|c|}{0.08} \\
\hline
\end{tabular}



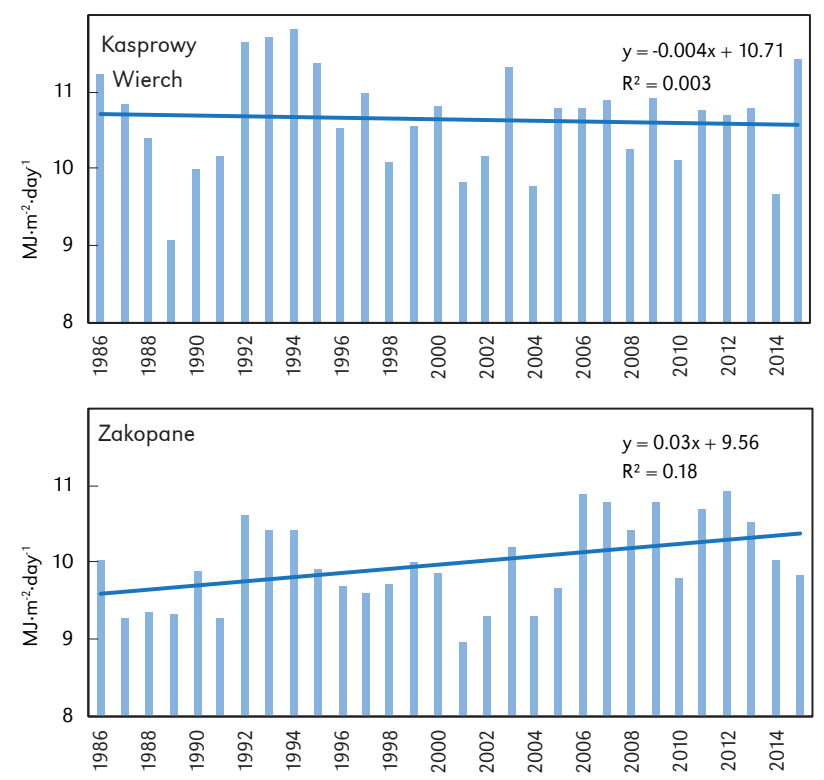

Figure 10. Multiannual course of the average daily sum of total radiation $\left(\mathrm{MJ} \cdot \mathrm{m}^{-2} \cdot \mathrm{day}^{-1}\right.$ ) at Kasprowy Wierch and in Zakopane (1986-2015). The graphs show trend lines, their equations and determination coefficients $\mathrm{R}^{2}$
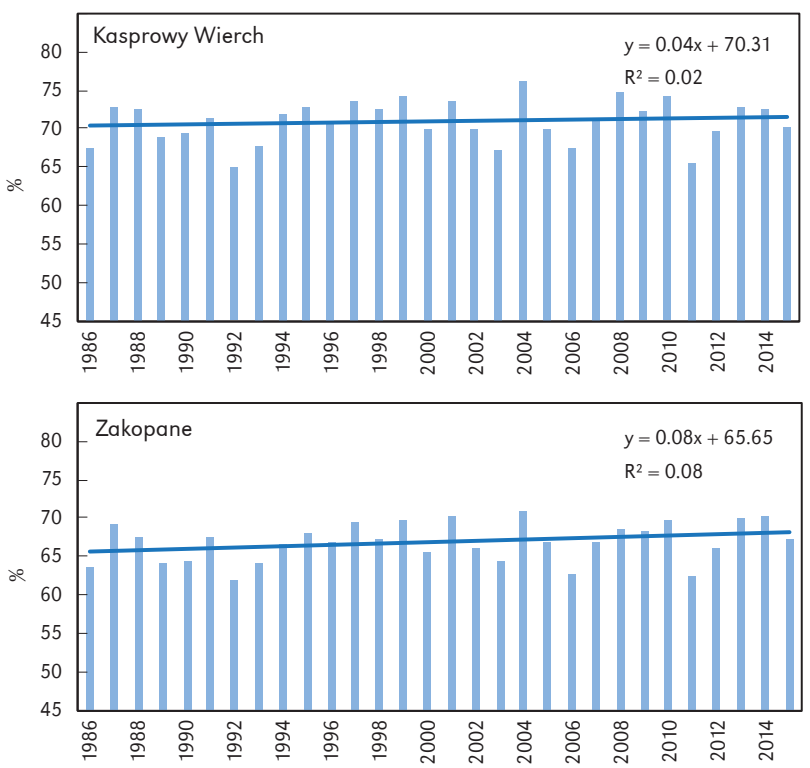

Figure 11. Multiannual course of the average cloud cover (\%) at Kasprowy Wierch and in Zakopane (1986-2015). The graphs show trend lines, their equations and determination coefficients $R^{2}$ 
cover in the analysed multiannual period was found at both stations in January. This corresponded to a significant decrease in the daily sums of radiation at Kasprowy Wierch, and an insignificant decrease in Zakopane.

\section{Discussion}

The obtained results highlight the strong impact of cloud cover on the formation of radiation conditions at the Earth's surface. Although in June the sum of solar radiation in the upper atmosphere is higher than in July, the values are lower at the Earth's surface, at the analysed Tatra stations. This is due to an increase in cloud cover of about 5\%.

The development of cloud cover has a modifying effect on the annual course of daily sums of total solar radiation. The annual cycle of daily sums of total radiation at Kasprowy Wierch and in Zakopane, resulting from the impact of astronomical factors, is not a sinusoid - it is characterized by a summer flattening, which is especially visible at the peak station. The annual maximum of the daily sums of total radiation is shifted towards May at the high-altitude station and towards July in Zakopane. These characteristics of the annual course of the daily sums of total radiation at the analysed stations can be considered as a repeated pattern, occurring regardless of the research period (Bogdańska \& Podogrocki 2000).

The average increase in the annual sum of total radiation from Zakopane to Kasprowy Wierch is $193 \mathrm{MJ} \cdot \mathrm{m}^{-2}$ per $1000 \mathrm{~m}$ (about 5.3\%). The highest increase during the year occurs in spring (10.8\% for every $1000 \mathrm{~m})$ and in winter (24.5\% for every $1000 \mathrm{~m}$ ). Similar relationships have been found in the Alps, where the increase in radiation with altitude is about $9-11 \%$ for every $1000 \mathrm{~m}$ (Sauberer \& Dirmhirn 1958, after Barry 2008).

The average daily sums of total solar radiation at Kasprowy Wierch and in Zakopane are highest with partial cloud cover (sunny days), and not with cloudless skies. In seasonal terms, this pattern applies in spring and autumn. It is often mentioned in the literature that, on days where the sky is partially covered by cumulus clouds, temporary values of radiation intensity may be higher than under the same conditions on cloudless days (e.g., Robinson 1977; Paál 1987; Monteith \& Unsworth 1988; Segal \& Davis 1992; Matuszko 2009). However, the reason for the observed pattern in this case is the very small number of days from which average values are calculated in the individual seasons. In the autumn, at both stations simultaneously, there were 15 cloudless days; there were only 9 in spring, and none of these days occurred in May. Thus, the average daily sum is lower than the corresponding sum on sunny days. The average daily sums of total solar radiation in summer and winter were highest on cloudless days. The average daily inflow of radiant energy and the maximum daily sums of total solar radiation were lowest on days with full cloud cover. Maximum sums occurred on cloudy days. This situation occurred in the summer, and on average over the year. In autumn and winter at Kasprowy Wierch, and in spring in Zakopane, the largest daily sums of total solar radiation, as well as the averages, occurred on sunny days. In terms of minimum sums, the highest values occurred throughout the year at both stations on cloudless days. The smallest daily sum of total radiation from spring to autumn, and on average throughout the year, was found at Kasprowy Wierch on overcast days, and in Zakopane on days with full cloud cover. Only in winter did the minimum value occur at Kasprowy Wierch on a cloudy day, and in Zakopane on an overcast day.

At Kasprowy Wierch, the lowest daily sums of total radiation in the period from September to February decreased to below $0.5 \mathrm{MJ} \cdot \mathrm{m}^{-2}$. The smallest sum of radiation in the analysed 30-year period at Kasprowy Wierch, at just $0.36 \mathrm{MJ} \cdot \mathrm{m}^{-2}$, was 100 times smaller than the maximum daily sum at this station. In Zakopane, the lowest daily sum, in November and December, had a value of hundredths of a $\mathrm{MJ} \cdot \mathrm{m}^{-2}$. On a day with full cloud cover on 15 November 1988, the daily sum of solar radiation was $0.04 \mathrm{MJ} \cdot \mathrm{m}^{-2}$, which was nearly 800 times smaller than the maximum sum. 
The increase in the amount of cloud cover over Poland in early summer is associated with a change in the circulation conditions. At the turn of May and June, the direction of geostrophic wind from SE to NW changes over Poland (Kożuchowski \& Żmudzka 2002). This change in the wind signals the arrival of the summer 'European monsoon' (KossowskaCezak 1994). The advection of cool and humid air masses from the north-west causes a significant increase in the amount of cloud cover over Poland (Żmudzka 2007). This increase is particularly high on the northern slope of the Carpathians, which force air to rise over the windward slopes. In autumn, the sums of radiation are lower than in spring, not only because of the smaller sums of non-atmospheric radiation, but also due to the significant increase in cloud cover, mainly layered.

In addition to astronomical conditions, the condition of the atmosphere is important in the formation of radiation conditions, including the amount of inflowing total radiation. This condition is dependent on several other factors, in addition to the amount of cloud cover, which were not taken into account in the analysis, such as turbidity and air pollution. The sun-diminishing impact of the atmosphere in Zakopane is greater than at Kasprowy Wierch throughout the year, apart from summer, despite the fact that cloud cover is greater at the peak station throughout the year. In Zakopane, a particular weakening of non-atmospheric radiation occurs during the cold part of the year, when the difference in the amount of cloud cover between the analysed stations is relatively small. On cloudless days in autumn and winter in Zakopane, the daily sums of total radiation are significantly lower than at Kasprowy Wierch. This situation may be caused, among other things, by air pollution, which is boosted by numerous emission sources, as well as frequent inversions of air temperature covering the lower part of the vertical profile of the Tatra chain. It may also be affected by the obstruction of the horizon at the Zakopane station, which is conditioned by its location on a concave slope.
In periods of high-pressure weather, with the settling of the air, it happens that a compact cover of layered clouds lies below the station at Kasprowy Wierch. On 57 days over the analysed multiannual period $(0.5 \%$ of all days), the average daily amount of cloud cover in Zakopane was 100\%, while at Kasprowy Wierch it was no more than $80 \%$.

For both stations, the highest percentage of non-atmospheric radiation reaches the Earth's surface in spring. This is the period during the year in which there is a relatively high frequency of Arctic air masses with high transparency over southern Poland (Niedźwiedź 2003). However, at the foot of the Tatras, the transmission coefficient is much lower than at Kasprowy Wierch, which may result from an extended heating season and the emission of pollutants from household furnaces (although lower than in the autumn/ winter season). In winter, at Kasprowy Wierch, the daily sums of solar radiation are the highest in the whole of Poland.

As the research has shown, the amount of the sky covered by clouds is an important feature of cloud cover - though not the only one - which has a significant impact on the amount of inflowing radiant energy. The composition type of the clouds and their position relative to the sun have a significant but not yet sufficiently explained effect (e.g., Monteith \& Unsworth 1988; Robinson 1977; Kuchinke \& Nunez 1999). These factors affect the amount of radiation by modifying the proportions of the components of total radiation (direct and scattered radiation). This aspect will be further researched in the Tatra region.

There is a positive trend in changes in the annual average daily sums of total radiation in Zakopane during the analysed multiannual period, which indicates a change of direction in the amount of inflowing radiant energy in relation to earlier periods (e.g., Bogdańska \& Podogrocki 2000). Negative trends in changes in the amount of radiation in the second half of the twentieth century (up to the 1990s) occurred over a large area of Central Europe (Russak 1990). The increase in the annual average daily sums of total 
radiation in Zakopane was mainly a consequence of a significant increase in the amount of radiation in the warm half of the year (in monthly terms: in April and August). This occurred despite the significant increase in cloud cover in Zakopane in this part of the year.

In this study, cloud cover was described using nephological characteristic days, which is one of the methods for describing the amount of cloud cover. The average daily cloud cover used to detect these days was calculated using eight synoptic terms, which means that, for the majority of the year, observations before and after sunset were used in the calculations, with the number of these observations changing throughout the year. The generally accepted methodology for determining characteristic days based on the amount of cloud cover may affect the obtained results, which is also related to the different daily course of the amount of cloud cover in the hot and cold parts of the year, and thus to the impact on the amount of cloud cover during the solar radiation inflow period. Behind these methodological considerations lies a probable lack of strict dependency of the daily sums of total solar radiation on the average daily amount of cloud cover (the correlation coefficient between these variables was -0.48 at Kasprowy Wierch, and -0.52 in Zakopane).

\section{Conclusion}

The main objective of the research was to determine the differences in inflow of solar energy to the Earth's surface between two stations located in the foothills and in the Tatras, as well as to examine the role of cloud cover in shaping radiation conditions. In addition, the study defined long-term change trends in daily sums of total radiation and in cloud cover. The study used daily data provided by the Institute of Meteorology and Water Management, concerning Zakopane and Kasprowy Wierch stations in the thirtyyear period 1986-2015. The cloud cover was described in terms of its size as well as the number of characteristic nephological days.
The influence of cloudiness on the inflow of radiant energy to the stations located at the foot and the peak of the Tatras manifests itself in:

- slowdown in the increase in daily sums of total radiation during summer; these daily sums start increasing from the winter solstice and the slowdown is particularly big in the high Tatras,

- the fact that the period with the biggest daily sums of total radiation in the year does not match the period when the longest day and the highest altitude of the Sun above the horizon are observed,

- significantly smaller daily sums of total radiation from mid-May to the end of August at the peak station than at the station lying at the foot of the mountains,

- bigger differences in daily sums of total radiation at the analysed stations occurring during the cold half of the year than during the warm half,

- daily sums of total radiation increasing more with altitude on sunny days than on all days on average. The difference between the stations in the size of the increase in average daily sums was particularly big on sunny days in summer. On overcast summer days, the average daily inflow of total radiation was the same at both stations.

A substantial increase in the amount of radiation was observed in the warm half of the year in Zakopane, despite a significant increase in cloud cover at the same time.

\section{Acknowledgements}

The results of the research carried out under the theme entitled 'Theoretical and experimental studies of the climate on a local scale' (No. BST-180200) were financed from a scientific grant awarded by the Ministry of Science and Higher Education.

\section{Editors' note:}

Unless otherwise stated, the sources of tables and figures are the authors', on the basis of their own research. 


\section{References}

Alexandersson H., Moberg A., 1997. Homogenization of Swedish temperature data. Part I: Homogeneity test for linear trends. International Journal of Climatology, vol. 17, no. 1, pp. 25-34.

Blumthaler M., Ambach W., Salzgeber M., 1994. Effects of cloudiness on global and diffuse UV irradiance in a high-mountain area. Theoretical and Applied Climatology, vol. 50, no. 1-2, pp. 23-30.

Bogdańska B., Podogrocki J., 2000. Variability of total solar radiation in Poland in the period 1961-1995. Materiały badawcze, Seria: Meteorologia, 30, Warszawa: Instytut Meteorologii i Gospodarki Wodnej.

Chiacchio M., Ewen T., Wild M., Chin M., DIEHL T., 2011. Decadal variability of aerosol optical depth in Europe and its relationship to the temporal shift of the North Atlantic Oscillation in the realm of dimming and brightening. Journal of Geophysical Research, vol. 116, pp. D02108.

Fedorowicz J., 1926. 50-lecie Stacji Meteorologicznej w Zakopanem. Wierchy, vol. 4, pp. 185187.

Feister U., Cabrol N., Häder D., 2015. UV irradiance enhancements by scattering of solar radiation from clouds. Atmosphere, vol. 6, no. 8, pp. 1211-1228.

Haurwitz B., 1945. Insolation in relation to cloudiness and cloud density. Journal of Meteorology, vol. 2, no. 3, pp. 154-166.

Heimo A., Philipona R., Fröhlich C., Marty Ch., OhmuRA A., 1998. The Swiss atmospheric radiation monitoring network CHARM [in:] Papers presented at the WMO Technical Conference on Meteorological and Environmental Instruments and Methods of Observation (TECO-98): Casablanca, Morocco, 13-15 May 1998, World Meteorological Organization.

Hess M., OleCKI Z., 1984. Variation of total solar radiation in the Carpathian area. Zeszyty Naukowe UJ, Prace Geograficzne, vol. 58, pp. 49-63.

Kasten F., Czeplak G., 1980. Solar and terrestrial radiation dependent on the amount and type of cloud. Solar Energy, vol. 24, pp. 177-190.

KhaliQ M.N., Ouarda T.B.M.J., 2007. On the critical values of the standard normal homogeneity test (SNHT). International Journal of Climatology, vol. 27, no., 5, pp. 681-687.

KIMBALL H.H., 1928. Amount of solar radiation that reaches the surface of the Earth on the land and on the sea and methods by which it is measured. Monthly Weather Review, vol. 56, no. 10, pp. 393-399.

KonČEK M. (ed.), 1974. Climate of the Tatras. Bratislava: Veda SAV.

Kossowska-Cezak U., 1994. O 'monsunie europejskim'. Przegląd Geofizyczny, vol. 39, no. 1, pp. 65-73.

KożUCHOWskı K., ŻMUDZKA E., 2002. Atmospheric circulation and its influence on the variability of air temperature in Poland. Przeglad Geograficzny, vol. 74, no. 4, pp. 357-365.

KuChinke C., Nunez M., 1999. Cloud transmission estimates of UV-B erythemal irradiance. Theoretical and Applied Climatology, vol. 63, no. 3-4, pp. 149-161.

LIEPERT B.G., 2002. Observed reductions of surface solar radiation at sites in the United States and worldwide from 1961 to 1990 . Geophysical Research Letters, vol. 29, no. 10: 61-1-61-4.

LUMB F.E., 1964. The influence of cloud on hourly amount of total solar radiation at the sea surface. Quarterly Journal of the Royal Meteorological Society, vol. 90, no. 383, pp. 43-56.

Marty C., Philipona R., Fröhlich C., Ohmura A., 2002. Altitude dependence of surface radiation fluxes and cloud forcing in the Alps: results from the alpine surface radiation budget network. Theoretical and Applied Climatology, vol. 72, no. 3-4, pp. 137-155.

Mateer C.L., 1963. On the relationship between global radiation and cloudiness at ocean station P. Archiv für Meteorologie, Geophysik und Bioklimatologie, Series B, vol. 12, no. 3, pp. 482490.

MatuszKo D., 2009. Wpływ zachmurzenia na usłonecznienie i całkowite promieniowanie słoneczne (na przykładzie krakowskiej serii pomiarów). Kraków: Wydawnictwo Uniwersytetu Jagiellońskiego.

MitCHeLl J.M., 1966. Climatic change: Report of a working group of the Commission for Climatology. WMO Technical Note, no. 79, Geneva: World Meteorological Organization. 
Monteith J.R.L., Unsworth M.H., 1988. Principles of environmental physics. London: Edward Arnold.

MöSER W., RAsChKE E., 1983. Mapping of global radiation and of cloudiness from METEOSAT image data. Meteorologische Rundschau, vol. 36, pp. 33-41.

Mueller R.W., Dagestad K.F., Ineichen P., Schroedter-Homscheidt M., Cros S., Dumortier D., Kuhlemann R., Olseth J.A., Piernavieja G., Reise C., Wald L., Heinemann D., 2004. Rethinking satellite-based solar irradiance modelling the SOLIS clear-sky module. Remote Sensing of Environment, vol. 91, pp. 160-174.

NiedźWiedź T., 2003. Częstość występowania mas powietrznych $w$ Polsce południowej w drugiej połowie XX wieku [in:] K. Błażejczyk, B. Krawczyk, M. Kuchcik, (eds.), Postępy w badaniach klimatycznych i bioklimatycznych, Prace Geograficzne, vol. 188, Warszawa: Instytut Geografii i Przestrzennego Zagospodarowania PAN, pp. 65-74.

NOAA, Solar Calculator, https://www.esrl.noaa. gov/gmd/grad/solcalc/ [10 April 2019].

Obrebska-Starklowa B., Hess M., Olecki Z., TrePIŃSKA J., KoWANETZ L., 1995. Klimat [in:] J. Warszyńska (ed.), Karpaty polskie: Przyroda, człowiek i jego działalność, Kraków: Wydawnictwo Uniwersytetu Jagiellońskiego.

Ohmura A., 2006. Observed long-term variations of solar irradiance at the Earth's surface [in:] Y. Calisesi, R.M. Bonnet, L. Gray, J. Langen, M. Lockwood (eds.), Solar Variability and Planetary Climates. Space Sciences Series of ISSI, vol 23. New York, NY: Springer, pp. 111-128.

OlECKI Z., 1989. Bilans promieniowania słonecznego w dorzeczu górnej Wisły. Rozprawy Habilitacyjne UJ, vol. 157, Kraków: Uniwersytet Jagielloński.

PAÁL A., 1987. Investigation of relationship between cloudiness and global radiation using METEOSAT images. Pure and Applied Geophysics, vol. 125, no. 1, pp. 109-120.

Podogrocki J., 2002. Z badań usłonecznienia w Warszawie [in:] G. Wójcik, K. Marciniak (eds.), Scientific activities of professor Władysław Gorczyński and their continuation: Climatological Symposium in Nicolaus Copernicus University, 16-17 September 1993, Toruń, pp. 147-152.
Pfeifroth U., Kothe S., Müller R., Trentmann J., Hollmann R., Fuchs P., Werscheck, M., 2017. Surface Radiation Data Set - Heliosat (SARAH) - Edition 2. Satellite Application Facility on Climate Monitoring.

Reiter R., Munzert K., Sladkovic R., 1982. Results of 5-year concurrent recordings of global, diffuse, and UV-radiation at three levels (700, 1800 , and $3000 \mathrm{~m}$ a.s.l.) in the Northern Alps. Archives for Meteorology, Geophysics, and Bioclimatology, Series B, vol. 30, no. 1-2, pp. 1-28.

RIMóczl-PAÁL A., 1985. Determination of surface global radiation from METEOSAT images using relative brightness as new parameter to characterize the cloudiness. Advances in Space Research, vol. 5, no. 6, pp. 329-332.

RoBinsON P.J., 1977. Measurements of downwards scattered solar radiation from isolated Cumulus clouds. Journal of Applied Meteorology, vol. 16, no. 6, pp. 620-625.

RUSSAK V., 1990. Trends of solar radiation, cloudiness and atmospheric transparency during recent decades in Estonia. Tellus B: Chemical and Physical Meteorology, vol. 42, no. 2, pp. 206-210.

Sauberer F., Dirmhirn I., 1958. Das Strahlungsklima [in:] F. Steinhauser, O. Eckel, F. Lauscher (eds), Klimatographie von Osterreich, Vienna: Springer, pp. 13-102, [after] Barry, R. G., 2008. Mountain weather and climate. Cambridge: Cambridge University Press.

Sanchez-Lorenzo A., Wild M., Trentmann J., 2013. Validation and stability assessment of the monthly mean CM SAF surface solar radiation dataset over Europe against a homogenized surface dataset (1983-2005). Remote Sensing of Environment, vol. 134, pp. 355-366.

Sanchez-Lorenzo A., Calbo J., Martin-Vide J., 2008. Spatial and temporal trends in sunshine duration over western Europe (1938-2004). Journal of Climate, vol. 21, no. 22, pp. 6089-6098.

Segal M., Davis J., 1992. The impact of deep cumulus reflection on the ground-level global irradiance. Journal of Applied Meteorology, vol. 31, no. 2, pp. 217-222.

Sidorenkov N.S., Orlov I.A., 2008. Atmospheric circulation epochs and climate changes. Russian Meteorology and Hydrology, vol. 33, no. 9, pp. 553-559. 
SKIBIŃSKI Z., FEDOROWICZ J., 1938. O promieniowaniu pozafiołkowym w Zakopanem: Pierwsze spostrzeżenia. Polska Gazeta Lekarska, vol. 17, Lwów: [s.n.], pp. 463-465.

Stenz E., 1933a. Mesures de la radiation solaire dans la Haute Tatra. Archives des Sciences Physiques et Naturelles, vol. 15, Geneve: Institut de Physique de l'Univ.

Stenz E., 1933b. Zimowy pomiar promieniowania słonecznego w Tatrach. Wierchy, vol. 11.

WoJkowskl J., 2015. Solar radiation [in:] K. Dabrowska, M. Guzik (eds.), Atlas of the Tatra Mountains - Abiotic Nature, Zakopane: Tatra National Park.
ŻMUDZKA E., 2007. Variability of cloud cover over Poland and its circulatory conditions (19512000). Warszawa: Wydawnictwo Uniwersytetu Warszawskiego.

ŻMUDZKA E., 2012. Nephological characteristic days - various exclusion criteria and their impact on test results. Przeglad Geofizyczny, vol. 57, no. 1, pp. 21-33. 